Article

\title{
Optimising Ambient Setting Bayer Derived Fly Ash Geopolymers
}

\author{
Evan Jamieson ${ }^{1,2}$, Catherine S. Kealley ${ }^{3}$, Arie van Riessen ${ }^{3, *}$ and Robert D. Hart ${ }^{3}$ \\ 1 School of Civil and Mechanical Engineering, Curtin University, GPO Box U1987, Perth, WA 6845, Australia; \\ evan.jamieson@curtin.edu.au \\ 2 Technology Delivery Group, Alcoa World Alumina, P.O. Box 161, Kwinana, WA 6966, Australia \\ 3 John de Laeter Centre, Curtin University, GPO Box U1987, Perth, WA 6845, Australia; \\ Cat.kealley@curtin.edu.au (C.S.K.) \\ * Correspondence: a.vanriessen@curtin.edu.au; Tel.: +61-8-9266-7090; Fax: +61-8-9266-2377
}

Academic Editor: Prabir K. Sarker

Received: 11 April 2016; Accepted: 11 May 2016; Published: 19 May 2016

\begin{abstract}
The Bayer process utilises high concentrations of caustic and elevated temperature to liberate alumina from bauxite, for the production of aluminium and other chemicals. Within Australia, this process results in 40 million tonnes of mineral residues (Red mud) each year. Over the same period, the energy production sector will produce 14 million tonnes of coal combustion products (Fly ash). Both industrial residues require impoundment storage, yet combining some of these components can produce geopolymers, an alternative to cement. Geopolymers derived from Bayer liquor and fly ash have been made successfully with a compressive strength in excess of $40 \mathrm{MPa}$ after oven curing. However, any product from these industries would require large volume applications with robust operational conditions to maximise utilisation. To facilitate potential unconfined large-scale production, Bayer derived fly ash geopolymers have been optimised to achieve ambient curing. Fly ash from two different power stations have been successfully trialled showing the versatility of the Bayer liquor-ash combination for making geopolymers.
\end{abstract}

Keywords: Bayer liquor; geopolymer; fly ash; ambient curing

\section{Introduction}

Aluminosilicate inorganic polymers or geopolymers are amorphous materials that have the potential to be an alternative for Ordinary Portland Cement (OPC) binders. Geopolymers have high compressive and flexural strength, high temperature resistance, and impressive acid resistance [1-4]. Another potential benefit of geopolymers is the significant reduction in $\mathrm{CO}_{2}$ emissions. Geopolymer production has been reported to create as little as $6 \%$ to $64 \%$ of the $\mathrm{CO}_{2}$ output compared to OPC production, depending on assessment methodology and lifecycle analysis [5-8]. Geopolymers have also been shown to immobilise waste within their three-dimensional structure $[9,10]$. Geopolymers have been considered as an alternative for OPC in applications such as cement pathways, pavers, mine backfill, railway sleepers (ties), sewerage pipes and earth retaining walls [11-13].

Geopolymers can be produced from a range of aluminate and silicate materials including metakaolin, fly ash, ground granulated blast furnace slags and mineral processing wastes. As such, most industrial precincts would produce a range of suitable feedstock to enable geopolymer production [14]. Other materials required for concrete production such as residue sand have been evaluated for construction purposes [15-18]. The use of multiple and varied geopolymer feedstock has led to a focus on understanding the chemistry of the amorphous reactive components. This in turn allows geopolymer products to be formulated with predictable performance properties, without trial and error [14,19-22]. The critical feedstock for geopolymers include: (i) caustic; (ii) soluble silica; 
and (iii) soluble alumina. All three materials must be available in large quantities and at appropriate cost for commercial application. In addition, sources of heat may be required as geopolymers are commonly cured at slightly elevated temperatures $\left(60-90^{\circ} \mathrm{C}\right)$. Thermal curing may be suitable for many product applications, but it is impractical in high volume markets such as in situ poured paths, roads and curbing. It is possible to design formulations for low calcium-based precursors that can be cured at ambient temperatures by the addition of calcium-containing compounds such as lime or ground granulated blast furnace slag [1,2,23-28].

Typical preparation of a geopolymer binder requires a highly concentrated caustic silicate solution to be added to a source of soluble silica and alumina (usually fly ash, metakaolin or ground granulated blast furnace slag) [27]. This procedure commonly targets a reactive Si/Al ratio of around two. Geopolymers may also be made by adding caustic sodium aluminate solution to sources of soluble silica [6,29-32]. Further development has shown that geopolymers can be made from silica rich, class $\mathrm{F}$ fly ash and alumina and caustic rich spent Bayer liquors (A "Bayer liquor" is a process solution derived from the hydrometallurgical thermal caustic extraction of alumina from bauxite ore) [10]. This achieves industrial synergies removing impurity laden liquor from Bayer process streams while providing an inexpensive source of caustic for the production of geopolymer concrete [33-35]. There are associated significant reductions in embodied energy of the resultant geopolymer [6].

For geopolymers to be economically viable, large volume production of products are required along with product acceptance [35-37]. To this aim, a variety of construction materials are envisaged, many requiring in situ and ambient temperature curing. This paper seeks to demonstrate ambient temperature curing of Bayer derived fly ash geopolymers as an enabler to further development. The present work has targeted compressive strength above $20 \mathrm{MPa}$, as this is typically specified for applications such as pathways, driveways and building footings (AS3727, 1993) [38].

\section{Experimental}

\subsection{Materials}

Bayer plant liquor was from Alcoa of Australia's Kwinana or Wagerup refineries. Spent liquor (post precipitation), was evaporated to provide the correct $\mathrm{H}_{2} \mathrm{O}$ to $\mathrm{Na}_{2} \mathrm{O}$ ratios in the final product. Refinery liquors are not constant and can vary between locations, highlighting the necessity of fundamental chemical analysis to maintain geopolymer ratios. Table 1 shows the analyses of the two liquors used in this project. Class F fly ash, used as a source of reactive silica and additional alumina, was obtained from Muja or Collie Power Stations, Western Australia. The total elemental composition is presented in Table 2, the phase composition in Table 3, the reactive components of the fly ash are given in Table 4 and particle sizes are provided in Table 5 . To achieve specific Si/Al ratios, silica fume (94\% purity) obtained from Doral Fused Materials Pty Ltd. (Rockingham, Western Australia, Australia) was added, as required. Particle size is included in Table 5.

Calcium additives for promotion of ambient curing were ground granulated blast furnace slag (Builders Choice, BFS20, BGC Cement, Canning Vale, Western Australia, Australia) and Hylime (Cockburn Cement, Munster, Australia), a manufactured hydrated lime product, predominantly Portlandite $\left(\mathrm{Ca}(\mathrm{OH})_{2}\right)$, that incorporates a small amount of air-entraining agent to enhance water retention and improve plasticity in mortars. Hylime contained 93 wt $\% \mathrm{Ca}(\mathrm{OH})_{2}$ as Portlandite, and the ground granulated blast furnace slag contained approximately $43 \mathrm{wt} \%$ of $\mathrm{CaO}$.

Table 1. Composition of Bayer liquors used to synthesise geopolymers.

\begin{tabular}{ccc}
\hline Source of Bayer Liquor & $\mathbf{A l}_{\mathbf{2}} \mathbf{O}_{\mathbf{3}}(\mathbf{g} / \mathrm{L})$ & $\mathbf{N a O H}(\mathrm{g} / \mathrm{L})$ \\
\hline Kwinana & 252.7 & 438.5 \\
Wagerup & 228.4 & 449.1 \\
\hline
\end{tabular}


Table 2. Bulk composition (XRF) of fly ash.

\begin{tabular}{ccc}
\hline \multirow{2}{*}{ Oxide } & Collie & Muja \\
\cline { 2 - 3 } & wt \% & wt \% \\
\hline $\mathrm{SiO}_{2}$ & $49.9(2)$ & $44.9(2)$ \\
$\mathrm{Al}_{2} \mathrm{O}_{3}$ & $24.8(2)$ & $32.5(2)$ \\
$\mathrm{Fe}_{2} \mathrm{O}_{3}$ & $16.60(4)$ & $10.6(4)$ \\
$\mathrm{CaO}$ & $1.8(1)$ & $2.0(1)$ \\
$\mathrm{K}_{2} \mathrm{O}$ & $0.61(8)$ & $0.69(8)$ \\
$\mathrm{TiO}_{2}$ & $1.36(2)$ & $1.67(3)$ \\
$\mathrm{MgO}$ & $1.31(6)$ & $1.44(6)$ \\
$\mathrm{Na}_{2} \mathrm{O}$ & $0.4(1)$ & $0.6(1)$ \\
$\mathrm{P}_{2} \mathrm{O}_{5}$ & $1.52(4)$ & $1.52(4)$ \\
$\mathrm{SrO}$ & $0.33(1)$ & $0.22(1)$ \\
$\mathrm{BaO}$ & $0.45(1)$ & $0.53(1)$ \\
Other (includes LOI) & $0.7(1)$ & $3.33(3)$ \\
$\mathrm{Si} / \mathrm{Al}$ (molar ratio) & $1.71(1)$ & $1.17(1)$ \\
\hline
\end{tabular}

Values in parentheses in this and all further tables correspond to the least significant figure in the estimated standard deviation to the left, all in weight percent. LOI is loss on ignition.

Table 3. The phase composition of the fly ash by Rietveld quantitative analysis.

\begin{tabular}{ccc}
\hline \multirow{2}{*}{ Mineral/Phase } & Collie & Muja \\
\cline { 2 - 3 } & wt $\%$ & wt \% \\
\hline Primary Quartz & $13(1)$ & $5.9(6)$ \\
Secondary Quartz & $11.0(2)$ & $4.9(3)$ \\
Hematite & $2.42(8)$ & $1.13(7)$ \\
Magnetite & $2.0(1)$ & $3.4(3)$ \\
Mullite & $14(1)$ & $28(1)$ \\
Maghemite C & $6.6(3)$ & - \\
Amorphous & $51(1)$ & $57(1)$ \\
\hline
\end{tabular}

Table 4. Composition of amorphous component of the fly ash.

\begin{tabular}{ccc}
\hline \multirow{2}{*}{ Oxide } & Collie & Muja \\
\cline { 2 - 3 } & $\mathbf{w t} \%$ & $\mathbf{w t} \%$ \\
\hline $\mathrm{SiO}_{2}$ & $21(2)$ & $26(2)$ \\
$\mathrm{Al}_{2} \mathrm{O}_{3}$ & $15(1)$ & $12(1)$ \\
sum of aluminosilicates & $36(3)$ & $38.1(4)$ \\
$\mathrm{Si} / \mathrm{Al}$ (molar ratio) & 1.2 & 1.8 \\
\hline
\end{tabular}

Table 5. Particle size and surface area of the fly ash and silica fume. Particle size (d) is presented as the cumulative volume diameter and the number in brackets represents the cut off value in percent.

\begin{tabular}{cccccc}
\hline Fly Ash/Fume & Surface Area $\left(\mathrm{m}^{\mathbf{2}} / \mathbf{c c}\right)$ & $\mathrm{d}(\mathbf{1 0})(\boldsymbol{\mu m})$ & $\mathrm{d} \mathbf{( 5 0 )}(\boldsymbol{\mu m})$ & $\mathrm{d}(\mathbf{8 0})(\boldsymbol{\mu m})$ & $\mathrm{d}(\mathbf{9 0})(\boldsymbol{\mu m})$ \\
\hline Collie & 1.01 & 2.7 & 16.0 & 49.3 & 81.9 \\
Muja & 2.24 & 1.1 & 4.4 & 13.2 & 24.6 \\
Silica Fume (SF98) & 18 & 0.3 & 0.5 & - & 0.8 \\
\hline
\end{tabular}

\subsection{Synthesis}

Geopolymer binder compositions were selected to target $\mathrm{Si} / \mathrm{Al}$ ratios of between 1.0 and 2.4 while keeping the $\mathrm{OH} / \mathrm{Al}$ ratio close to 0.8 or lower. Unless stated elsewhere in the text, the standard geopolymer binder composition utilised was $\mathrm{Si} / \mathrm{Al}=2.3$ and $\mathrm{OH} / \mathrm{Al}=0.8$. 
The dry powders were mixed together, and then Bayer liquor and water were added by mixing for a period of ten minutes before being placed into $25 \mathrm{~mm}$ diameter vials. Each sample was prodded with a rod during loading in order to remove air bubbles. Samples were sealed then cured at either $20{ }^{\circ} \mathrm{C}, 60{ }^{\circ} \mathrm{C}, 70{ }^{\circ} \mathrm{C}, 80^{\circ} \mathrm{C}$ or $90{ }^{\circ} \mathrm{C}$ for $24 \mathrm{~h}$, then left at room temperature for seven days prior to compressive strength testing.

\subsection{Characterisation}

The composition of the reactive amorphous component of the fly ash was determined by subtracting the crystalline composition of the fly ash determined by quantitative the XRD phase analysis from the bulk chemical composition total analysis determined by XRF, as described elsewhere [19].

Compressive strength tests were carried out in accordance with ASTM C39 [39] using a Lloyds Instruments 6000R compressive/tensile strength machine (Bognor Regis, UK) fitted with a $50 \mathrm{kN}$ load cell. A minimum of six samples ( $25 \mathrm{~mm}$ diameter and $50 \mathrm{~mm}$ length) from each formulation were tested and the mean and standard deviations reported.

Polished samples for SEM/EDS analysis were mounted on an aluminium stub using carbon tape and then coated with carbon or platinum and observed using a Zeiss NEON 40 EsB scanning electron microscope (Oberkochen, Germany). The microscope was coupled with an Oxford Instruments Energy Dispersive X-ray Spectrometer (High Wycombe, UK) for elemental analysis. Analysis of collected spectra was carried out using Oxford Inca software (High Wycombe, UK).

\section{Results}

\subsection{Curing Temperature}

Sealed samples of Collie fly ash/Bayer liquor geopolymer were cured for $24 \mathrm{~h}$ from 60 to $90{ }^{\circ} \mathrm{C}$ followed by resting for six days at ambient temperature. Different curing temperatures of sealed samples appear to have little impact upon compressive strength as shown in Figure 1.

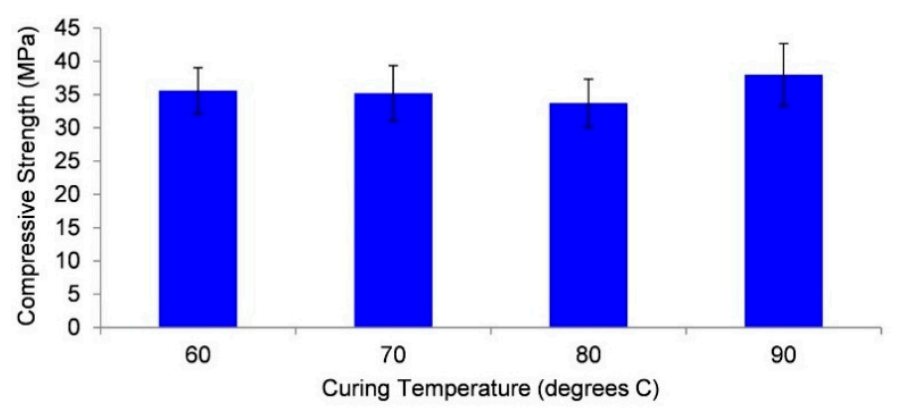

Figure 1. Seven-day compressive strength results from oven cured Collie fly ash/Bayer liquor geopolymer samples.

Figure 1 shows that the compressive strength after seven days of Collie fly ash/Bayer liquor geopolymer remains consistent at approximately $35 \mathrm{MPa}$ over a curing $(24 \mathrm{~h})$ temperature range of 60 to $90^{\circ} \mathrm{C}$. The ability to maintain constant strength with variable curing temperature is in contrast to others who have found increased curing temperatures above $60^{\circ} \mathrm{C}$, resulting in lower compressive strength [40]. This difference may be a result of the source of fly ash but could be due to the small sample volume and the sealed curing environment. The advantage is sufficient to warrant further investigation on larger scale samples. 


\subsection{Silica Fume Content}

Silica fume was added to geopolymer paste mixes to achieve targeted $\mathrm{Si} / \mathrm{Al}$ ratios. The addition of silica fume reduced the workability of the mixture. Geopolymer samples made from Collie or Muja fly ash were oven cured at $70{ }^{\circ} \mathrm{C}$ for $24 \mathrm{~h}$ in a sealed vial. Figure 2 shows a linear relationship between the targeted $\mathrm{Si} / \mathrm{Al}$ ratio and the compressive strength.

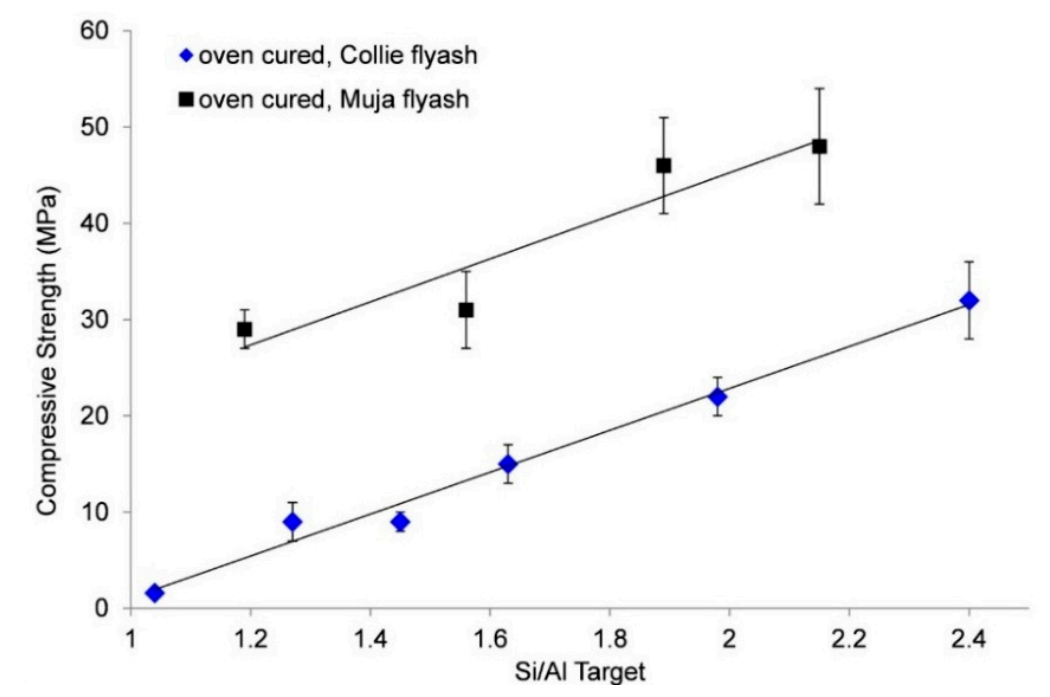

Figure 2. Silica fume addition to Muja fly ash/Bayer liquor geopolymers. Change in compressive strength versus targeted $\mathrm{Si} / \mathrm{Al}$ for oven cured samples.

From Figure 2, it is clear that increasing the $\mathrm{Si} / \mathrm{Al}$ ratio increases the compressive strength for both sources of fly ash. However, it is not possible to ascertain if the increased strength comes from increased geopolymer gel formation or a separate silica rich phase.

To determine the role of the silica fume, the $\mathrm{Si} / \mathrm{Al}$ of the geopolymer gel was measured by SEM/EDS. The measured Si / Al ratio was then compared to the targeted ratio. For Collie fly ash geopolymers, the targeted $\mathrm{Si} / \mathrm{Al}$ and measured $\mathrm{Si} / \mathrm{Al}$ (EDS) are similar above ratio 1.6 (Figure 3) and are identical at $\mathrm{Si} / \mathrm{Al}$ of 2.4 This suggests that all of the reactive $\mathrm{Si}$ and $\mathrm{Al}$ in the fly ash, plus all of the silica fume, has been consumed.

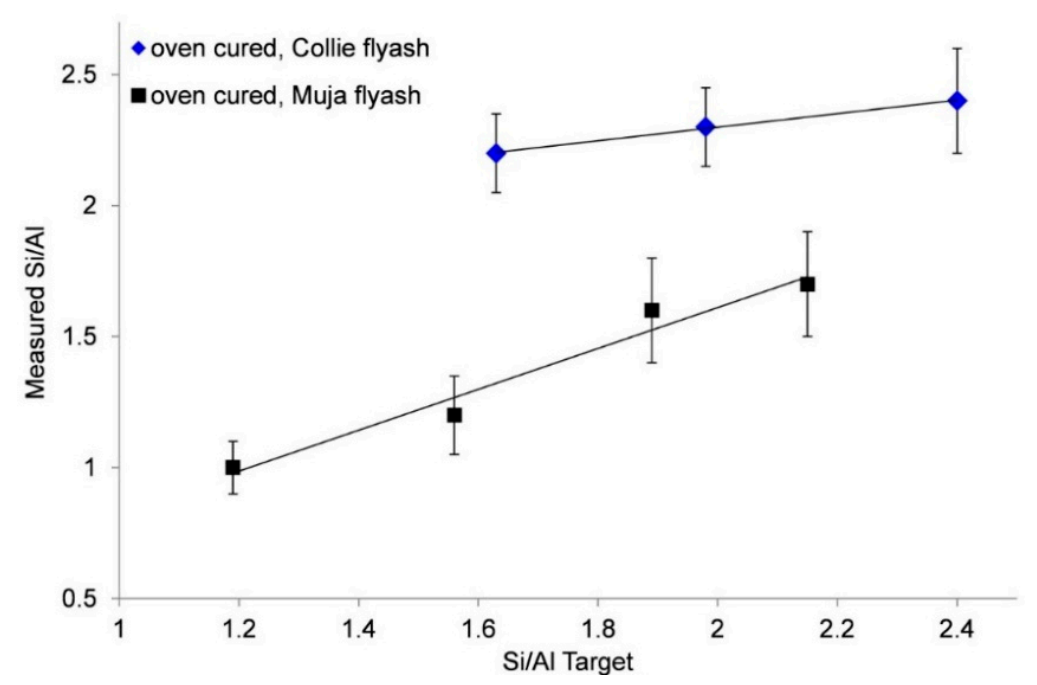

Figure 3. Variation in targeted $\mathrm{Si} / \mathrm{Al}$ versus measured $\mathrm{Si} / \mathrm{Al}$ of oven cured Collie and Muja fly ash/Bayer liquor geopolymers. 
Comparison of the targeted $\mathrm{Si} / \mathrm{Al}$ with measured $\mathrm{Si} / \mathrm{Al}$ for the Muja fly ash geopolymer (Figure 3) showed that the measured values were below the targeted values, indicating that not all of the extra $\mathrm{Si}$ from the silica fume is being incorporated into the geopolymer. It is thought that the smaller particle size distribution of the Muja fly ash and higher reactivity may result in less added silica being utilised. It is envisaged that if the fly ash dissolves faster than the silica fume, then the geopolymer condenses with a lower than expected $\mathrm{Si} / \mathrm{Al}$ leaving excess silica fume in the structure.

Analysis by XRD (Figure 4) has shown the presence of zeolite (sodalite) with peak intensity higher at lower $\mathrm{Si}$ / $\mathrm{Al}$ ratios. It is not clear if the presence of sodalite reduces the strength of the geopolymer, or if it is an artefact of incomplete geopolymerisation.

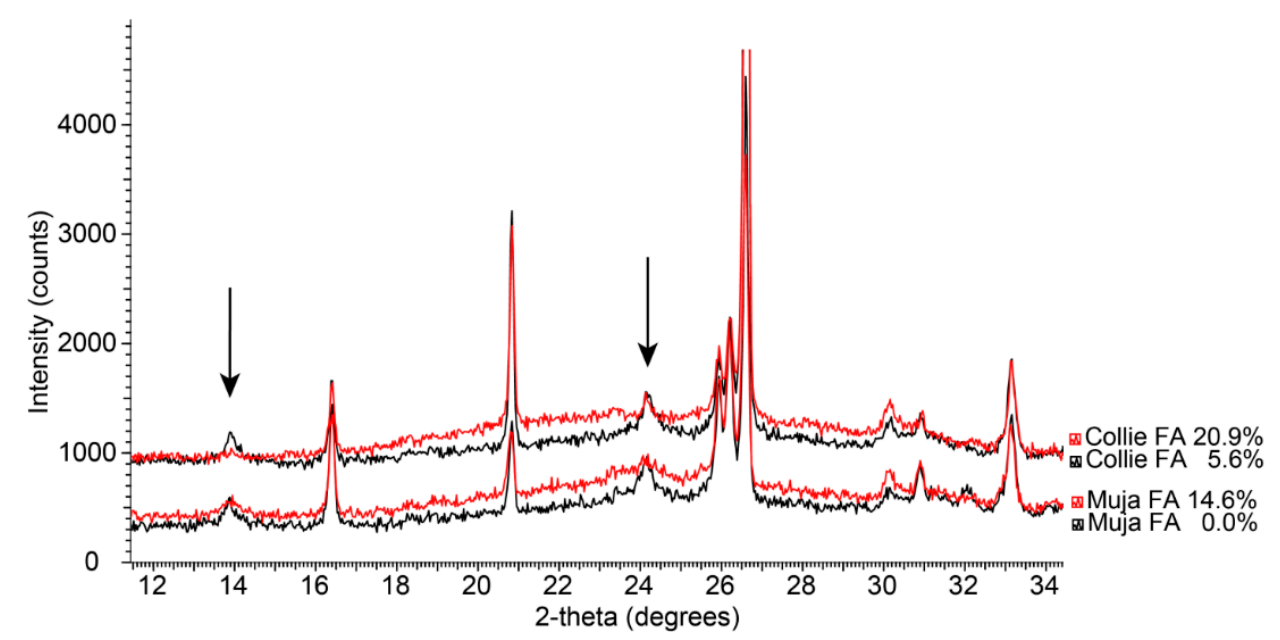

Figure 4. A comparison of the XRD patterns $\left(11^{\circ}-35^{\circ} 2 \theta\right)$ collected from Collie and Muja fly ash geopolymers with varying levels of silica fume. Note: The patterns have been offset vertically to improve clarity. The oven-cured samples were cured for $24 \mathrm{~h}$ at $70{ }^{\circ} \mathrm{C}$. The most intense reflections of the sodalite phase are highlighted with arrows.

For the oven-cured geopolymer pastes, both Collie and Muja fly ash based samples (Figure 2) showed an increase in the compressive strength with increased silica fume content. However, Muja fly ash geopolymer with a low $\mathrm{Si} / \mathrm{Al}=1.19$ (no added silica fume) still had a compressive strength of $29 \mathrm{MPa}$, well above the target of $20 \mathrm{MPa}$.

\subsection{Ambient Curing}

For many high volume premixed geopolymer applications, it is not feasible to cure at elevated temperatures. Thus, ambient curing is required. The incorporation of $\mathrm{Ca}(\mathrm{OH})_{2}$ or ground granulated blast furnace slag into the geopolymer mixture facilitates ambient curing. Ground granulated blast furnace slag is significantly less expensive than $\mathrm{Ca}(\mathrm{OH})_{2}$; however, larger quantities are required to achieve a compressive strength of $20 \mathrm{MPa}$.

Samples of Collie fly ash/Bayer liquor geopolymer were produced with different levels of Hylime $\left(\mathrm{Ca}(\mathrm{OH})_{2}\right)$. Figure 5 shows the seven-day compressive strength for samples cured at ambient temperature (approximately $22{ }^{\circ} \mathrm{C}$ ). The strength increases with increasing $\mathrm{Ca}(\mathrm{OH})_{2}$ content with mixtures of $4 \mathrm{wt} \%$ or higher $\mathrm{Ca}(\mathrm{OH})_{2}$ achieving the desired level (>20 MPa). 


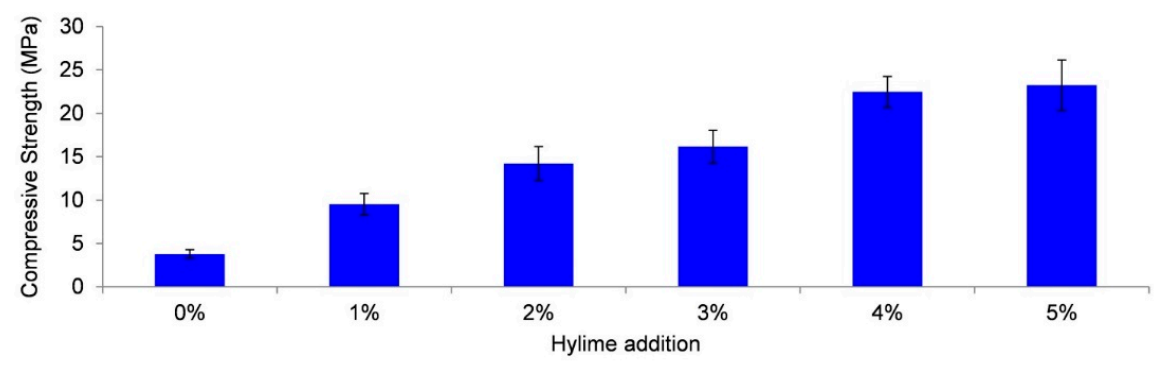

Figure 5. Seven-day compressive strength results for ambient cured Collie fly ash/Bayer liquor geopolymer samples with increasing $\mathrm{Ca}(\mathrm{OH})_{2}$ (Hylime) content (wt \%).

Phase identification with XRD data (Figure 6) shows that even at the highest concentrations $\left(5 \mathrm{wt} \%\right.$ of $\left.\mathrm{Ca}(\mathrm{OH})_{2}\right)$, Portlandite is not present as a separate crystalline phase but is incorporated in the geopolymer structure. Phases identified in the geopolymer paste are quartz, mullite, hematite and magnetite. There was an absence of sodalite compared to the oven cured samples in Figure 4.

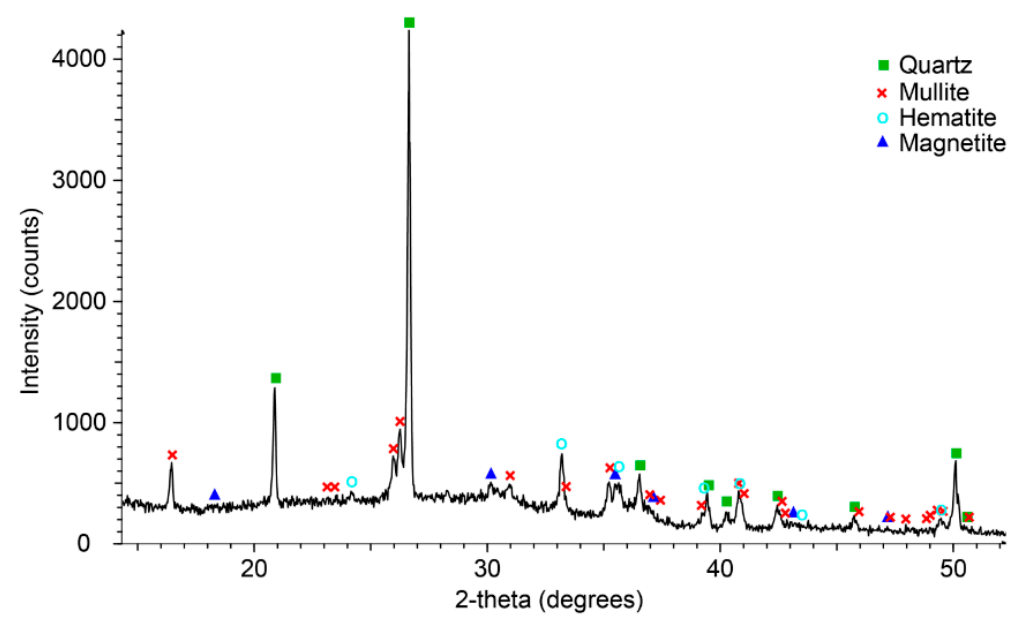

Figure 6. XRD pattern showing phase identification of the Collie fly ash/Bayer liquor based geopolymer paste with 5 wt $\% \mathrm{Ca}(\mathrm{OH})_{2}$ (Hylime).

Ground granulated blast furnace slag (Builders slag) is an industrial residue that can be used as a source of calcium (42.9 wt \% CaO). Samples of Muja fly ash/Bayer liquor geopolymer were produced utilising ground granulated blast furnace slag or Hylime for direct comparison. Figure 7 shows the comparative compressive strengths after seven days of ambient cure.

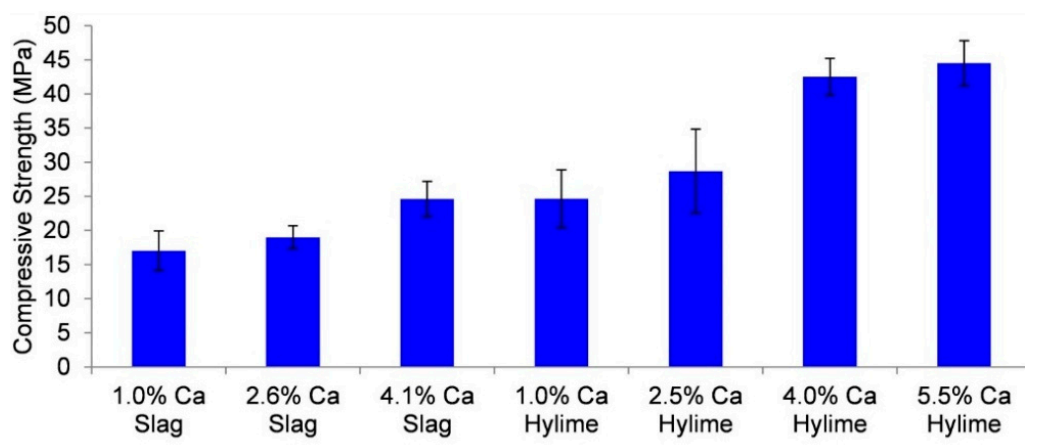

Figure 7. Muja fly ash/Bayer liquor-seven-day ambient cure compressive strength for calcium from different sources. 
For similar calcium content, it is evident that Hylime $\left(\mathrm{Ca}(\mathrm{OH})_{2}\right)$ is more effective at strength generation. It is understood that the particle size of the ground granulated blast furnace slag will dictate how readily the calcium is provided for the geopolymerisation process. Having a large impact upon strength, it would appear essential for any production process to ensure strict quality control/quality assurance upon the calcium delivery reagent.

The results demonstrate that Muja fly ash derived geopolymer (Figure 7) has higher compressive strength compared to Collie fly ash derived geopolymer (Figure 5). The Muja product also requires less calcium to achieve the ambient cure compressive strengths target. It is believed that the higher surface area of Muja ash (Table 5) contributed to improved alkali reactivity leading to greater geopolymer formation.

Figure 8 shows the XRD patterns collected from $1.0 \mathrm{wt} \%$ and $5.5 \mathrm{wt} \%$ calcium addition from $\mathrm{Ca}(\mathrm{OH})_{2}$ to Muja fly ash based geopolymers. There is a marginal increase in the amorphous geopolymer component for the $5.5 \mathrm{wt} \%$ sample, recognisable from the broad elevation in the pattern centred at $\sim 28^{\circ} 2 \theta$ (Figure 8). It is clear that no new phases have been formed by adding the $\mathrm{Ca}(\mathrm{OH})_{2}$ at either 1 or $5.5 \mathrm{wt} \%$ and curing at ambient temperature. It is apparent that the presence of Ca in samples cured at ambient temperature facilitates geopolymerisation leading to a strength increase [41].

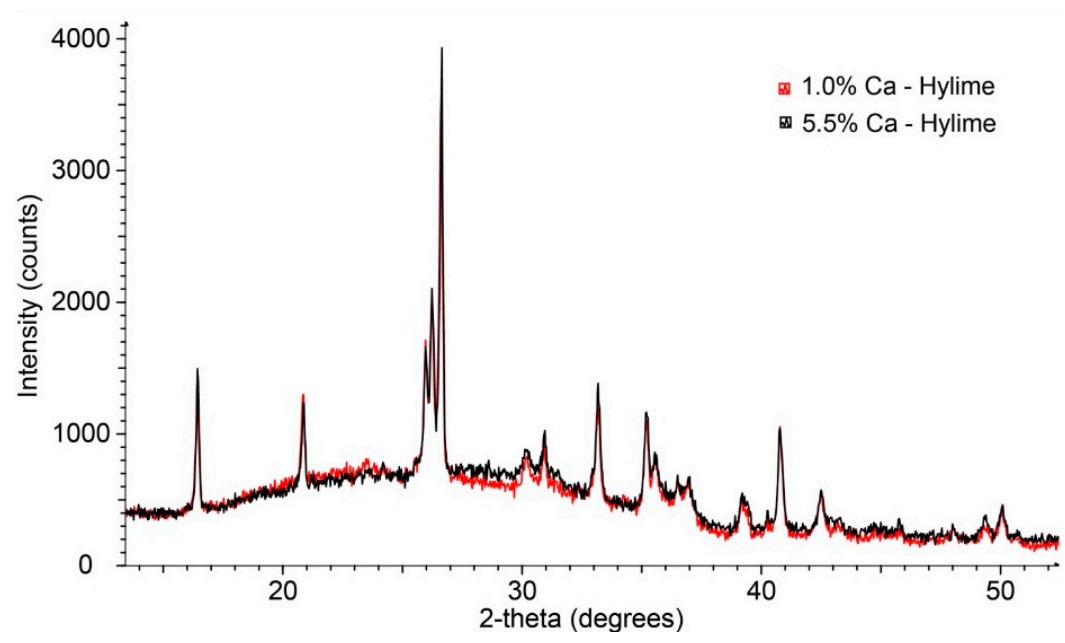

Figure 8. A selected portion of the XRD patterns from Muja fly ash/Bayer liquor geopolymer with 1.0 and $5 \mathrm{wt} \%$ addition of $\mathrm{Ca}(\mathrm{OH})_{2}$.

It is apparent that addition of calcium to the formulation of Bayer derived fly ash geopolymer results in ambient temperature curing with increasing calcium resulting in higher compressive strength. The target compressive strength of $20 \mathrm{MPa}$ is achieved with there being no discernible changes to the formation of geopolymer.

\section{Conclusions}

For a geopolymer concrete binding agent to be suitable for the replacement of Ordinary Portland Cement, the ability to cure at ambient temperature is considered essential to maximise the market opportunities. The novel approach of using Bayer process liquor as the activating solution for the manufacturing of geopolymers has opened the possibility of industrial scale synergy with significant reductions in product embodied energy. This paper has demonstrated that Bayer derived fly ash geopolymer formulations can be modified to achieve ambient cure.

Calcium was added to formulations utilising Collie or Muja power station fly ash to manufacture ambient temperature cured, Bayer derived geopolymer, achieving a minimum $20 \mathrm{MPa}$ compressive strength. 
Geopolymers made from Muja fly ash required less calcium addition yet resulted in a higher compressive strength than those made from Collie fly ash. This is believed to be a surface area effect of the fly ash resulting in greater reactivity.

The availability of calcium to the geopolymer appears critical to the product compressive strength. This would indicate that well defined calcium reagents are required for quality control and quality assurance.

The use of multiple industrial by-products to manufacture ambient curing geopolymers is a major step forward towards introducing commercially viable alternatives to Ordinary Portland Cement.

Acknowledgments: Project funds were provided by Alcoa to the Cooperative Centre for Sustainable Resource Processing as part of support for project 132.

Author Contributions: Evan Jamieson and Arie van Riessen conceived and designed the experiments; Catherine S. Kealley and Robert D. Hart performed the experiments and Catherine S. Kealley analysed the XRD data; Catherine S. Kealley, Evan Jamieson and Arie van Riessen wrote the paper.

Conflicts of Interest: The authors declare no conflict of interest.

\section{References}

1. Rangan, B.V. Studies on Fly Ash-Based Geopolymer Concrete. Malays. Constr. Res. J. 2008, 3, 1-20.

2. Rangan, B.V. Low-Calcium, Fly-Ash-Based Geopolymer Concrete. In Concrete Construction Engineering Handbook; Taylor and Francis Group: Boca Raton, FL, USA, 2008.

3. Rickard, W.; van Riessen, A.; Walls, P. Thermal Character of Geopolymers Synthesized from Class F Fly Ash Containing High Concentrations of Iron and a-Quartz. Int. J. Appl. Ceram. Technol. 2010, 7, 81-88. [CrossRef]

4. Temuujin, J.; Minjigmaa, A.; Lee, M.; Chen-Tan, N.; van Riessen, A. Characterisation of class F fly ash geopolymer pastes immersed in acid and alkaline solutions. Cem. Concr. Compos. 2011, 33, 1086-1091. [CrossRef]

5. McLellan, B.; Williams, R.; Lay, J.; van Riessen, A.; Corder, G. Costs and carbon emissions for geopolymer pastes in comparison to ordinary Portland cement. J. Clean. Prod. 2011, 19, 1080-1090. [CrossRef]

6. Jamieson, E.; McLellan, B.; van Riessen, A.; Nikraz, H. Embodied energy of Bayer derived Geopolymers. J. Clean. Prod. 2015, 99, 112-118. [CrossRef]

7. Davidovits, J. Global Warning Impact on the cement and aggregate industries. World Resour. Rev. 1994, 6, 263-278.

8. Davidovits, J. Environmentally driven geopolymer cement applications. In Proceedings of the Geopolymer 3rd International Conference: Turning Potential into Profit, Melbourne, Australia, 28-29 October 2002; Williams, J.R., Ed.; Geopolymer Institute: Melbourne, Australia, 2002.

9. Tavor, D.; Wolfson, A.; Shamaev, A.; Shvarzman, A. Recycling of industrial waste water by its immobilization in geopolymer cement. Ind. Eng. Chem. Res. 2007, 46, 6801-6805. [CrossRef]

10. Jamieson, E. Method for Management of Contaminants in Alkaline Process Liquors. International Patent WO 2008/017109 A1, 14 February 2008.

11. Gourley, J. Geopolymers; opportunities for environmentally friendly construction materials. In Proceedings of the Materials 2003 Conference: Adaptive Materials for a Modern Society, Sydney, Australia, 1-3 October 2003.

12. Gourley, J.; Johnson, G. Developments in Geopolymer Precast Concrete. In Proceedings of the International Workshop on Geopolymers and Geopolymer Concrete, Perth, Australia, 28-29 September 2005.

13. Southam, D.; Brent, G.; Felipe, F.; Carr, C.; Hart, R.; Wright, K. Towards More Sustainable Mine Fills-Replacement of Ordinary Portland Cement with Geopolymer Cements. In Proceedings of the World Gold Conference, Cairns, Australia, 22-24 October 2007; pp. 22-24.

14. Hart, R.; Lowe, J.; Southam, D.; Perera, D.; Walls, P.; Vance, E.; Gourley, T.; Wright, K. Aluminosilicate inorganic polymers from waste materials. In Proceedings of the Green Processing, Third International Conference on Sustainable Processing of Minerals and Metals, Newcastle, Australia, 5-6 June 2006; pp. 93-103.

15. Sriwahyuni, A.; Nikraz, H.; Jamieson, E.; Cooling, D. Sustainable use of bauxite residue sand (red sand) in concrete. In Proceedings of the Green Processing, Third International Conference on Sustainable Processing of Minerals and Metals, Newcastle, Australia, 5-6 June 2006; pp. 105-122. 
16. Jitsangiam, P.; Nikraz, H.; Jamieson, E. Sustainable use of a Bauxite Residue (red sand) in terms of Roadway Materials. In Proceedings of the 2nd International Conference on Sustainable Engineering and Science, Auckland, New Zealand, 20-23 February 2007.

17. Jitsangiam, P.; Nikraz, H.; Jamieson, E.; Kitanovich, R.; Siripun, K. Sustainable use of a Bauxite Residue (red sand) as Highway Embankment Materials. In Proceedings of the 3rd International Conference on Sustainability Engineering and Science, Auckland, New Zealand, 9-12 December 2008; The New Zealand Society for Sustainability Engineering and Science: Auckland, New Zealand, 2008.

18. Attiwell, S.; Jamieson, E.; Jones, A.; Cooling, D.; Myers, L.; Lee, F.; Malley, I.; Tate, D.; MacDonald, A.; Ketelsen, T.; et al. Demonstration trials for the use of Readygrit ${ }^{\circledR}$. In Proceedings of the 10th International Alumina Quality Workshop, Perth, Australia, 19-24 April 2015; Volume 10, pp. 187-196.

19. Williams, R.; van Riessen, A. Determination of the Reactive Component of Fly Ashes for Geopolymer Production Using XRF and XRD. Fuel 2010, 89, 3683-3692. [CrossRef]

20. Williams, R.; Hart, R.; van Riessen, A. Quantification of the Extent of Reaction of Metakaolin-Based Geopolymers. J. Am. Ceram. Soc. 2011, 94, 2663-2670. [CrossRef]

21. Chen-Tan, N.; van Riessen, A.; Ly, C.; Southam, D. Determining the reactivity of a fly ash for production of Geopolymer. J. Am. Ceram. Soc. 2009, 92, 881-887. [CrossRef]

22. Rickard, W.; Williams, R.; Temuujin, J.; van Riessen, A. Assessing the suitability of three Australian fly ashes as an aluminosilicate source for geopolymers in high temperature applications. Mater. Sci. Eng. A 2011, 528, 3390-3397. [CrossRef]

23. Hardjito, D.; Wallah, S.; Sumajouw, D.; Rangan, B. On the Development of Fly Ash-Based Geopolymer Concrete. ACI Mater. J. 2004, 101, 467-472.

24. Davidovits, J. Geopolymer Chemistry E Applications, 2nd ed.; Institut Géopolymère: Saint-Quentin, France, 2008; Chapter 25; pp. 526-527.

25. Xu, H.; van Deventer, J. Geopolymerisation of multiple minerals. Miner. Eng. 2002, 15, 1131-1139. [CrossRef]

26. Khater, H. Effect of Calcium on Geopolymerization of Aluminosilicate Wastes. J. Mater. Civ. Eng. 2012, 24, 92-101. [CrossRef]

27. Ferone, C.; Colangelo, F.; Messina, F.; Santoro, L.; Cioffi, R. Recycling of pre-washed municipal solid waste incinerator fly ash in the manufacturing of low temperature setting geopolymer materials. Materials 2013, 6, 3420-3437. [CrossRef]

28. Deb, P.S.; Nath, P.; Sarker, K. The effects of ground granulated blast-furnace slag blending with fly ash and activator content on the workability and strength properties of geopolymer concrete cured at ambient temperature. Mater. Des. 2014, 62, 32-39. [CrossRef]

29. Brew, D.; MacKenzie, K. Geopolymer synthesis using silica fume and sodium aluminate. J. Mater. Sci. 2007, 42, 3990-3993. [CrossRef]

30. Phair, J.; van Deventer, J. Characterization of fly-ash-based geopolymeric binders activated with sodium aluminate. Ind. Eng. Chem. Res. 2002, 41, 4242-4251. [CrossRef]

31. Masi, G.; Rickard, W.D.A.; Bignozzi, M.C.; van Riessen, A. The effect of organic and inorganic fibres on the mechanical and thermal properties of aluminate activated geopolymers. Compos. Part B 2015, 76, 218-228. [CrossRef]

32. Masi, G.; Rickard, W.D.A.; Vickers, L.; Bignozzi, M.C.; van Riessen, A. A comparison between different foaming methods for the synthesis of light weight geopolymers. Ceram. Int. 2014, 40, 13891-13902. [CrossRef]

33. Van Riessen, A.; Jamieson, E.; Kealley, C.; Hart, R.; Williams, R. Bayer-Geopolymers, an exploration of synergy between the alumina and geopolymer industries. Cem. Concr. Compos. 2013, 41, 21-33. [CrossRef]

34. Jamieson, E.; van Riessen, A.; Kealley, C.; Hart, R. Development of Bayer Geopolymer Paste and use as Concrete. In Proceedings of the 9th International Alumina Quality Workshop, Perth, Australia, 18-22 March 2012; Volume 9, pp. 296-299.

35. Jamieson, E. Development and Utilisation of Bayer Process by-Products. Ph.D. Thesis, Curtin University, Perth, Australia, October 2013.

36. Jamieson, E.; Penna, B.; van Riessen, A.; Nikraz, H. Bayer-Fly ash geopolymers: Development and application. In Proceedings of the 10th International Alumina Quality Workshop, Perth, Australia, 19-24 April 2015; Volume 10, pp. 197-204.

37. Van Deventer, J.; Provis, J.; Duxson, P.; Brice, D. Chemical research and climate change as drivers in the commercial adoption of alkali activated materials. Waste Biomass Valoriz. 2010, 1, 145-155. [CrossRef] 
38. Guide to Residential Pavements; Australian Standard 3727; Standards Australia: Homebush, Australia, 1993.

39. Standard Test Method for Compressive Strength of Cylindrical Concrete Specimens; ASTM C39; ASTM: West Conshohocken, PA, USA, 2012.

40. Hardjito, D.; Cheak, C.C.; Ing, C.H.L. Strength and Setting Times of Low Calcium Fly Ash-based Geopolymer Mortar. Mod. Appl. Sci. 2008, 2, 3-11. [CrossRef]

41. Temuujin, J.; van Riessen, A.; Williams, R. Influence of calcium compounds on the mechanical properties of fly ash geopolymer pastes. J. Hazard. Mater. 2009, 167, 82-88. [CrossRef] [PubMed]

(C) 2016 by the authors; licensee MDPI, Basel, Switzerland. This article is an open access article distributed under the terms and conditions of the Creative Commons Attribution (CC-BY) license (http:/ / creativecommons.org/licenses/by/4.0/). 